\title{
Contemporary Religiosity and the Absence of Solidarity With Those in Need
}

\author{
Ivana Noble \\ Charles University
}

\begin{abstract}
The article uses an adapted version of the multidimensional theory of religion to explore changes in contemporary religiosity in Central Europe, with a special focus on the Czech Republic. It asks whether there are any possible connections between the current absence of welcome of refugees, and the fact that the dominant religiosity that replaced the secularist ideology despises religious dogmas and institutions. It asks how people believing in "something", who do not wish to define that "something" or share its vision with others, can make an informed and healthy judgment and make themselves capable of solidarity with others. The final part of the article returns to the possibilities of strengthening precisely those dimensions of religion that have been downplayed, yet without unrealistic expectations that people would move back to the form of religiosity their parents, but more often already their great-grandparents, left behind.
\end{abstract}

\section{Keywords}

religion and religiosity in Visegrad countries; secularization; post-secularization; spirituality; social solidarity; refugees; multidimensinal theory of religion; Ninian Smart

In this article, I will concentrate on the question of whether shifts in mainstream religiosity in society go hand in hand with growing problems when it comes to agreeing on human values and on joint action in times of need. As an example, I will consider responses to the recent refugee situation. In the first part, I will present some data on this situation, with particular attention on the Visegrad countries. In two of these four countries, namely Poland and Slovakia, there is still strong attachment to traditional religion, whereas in the other two countries, the Czech Republic and Hungary, secularization came early and atheism or agnosticism has been the dominant conviction for several generations. I will ask what role in the changes is still played by the Communist past, and why in Western European countries a similar decline of traditional religions and rise of new forms of religiosity tend to dominate.

\footnotetext{
* Ivana Noble, Ecumenical Institute, Protestant Theological Faculty, Charles University, Černá 9 (PO BOX 529), 11555 Prague, Czech Republic; noble@etf.cuni.cz. This work has been supported by Charles University Research Centre program No. 204052.
} 


\section{Contemporary Religiosity and the Absence of Solidarity With Those in Need}

Then, I show how a dimensional theory of religion could help in examining the current religious scene. Here, I refer to empirical research mapping the shifts in the religious terrain in Europe, and use multidisciplinary tools for interpreting the current picture. I use the Czech Republic as an example, since both Western and Eastern European paradigms of the coexistence of secularization, post-secularization and re-composition of religion can be found there. My particular question remains as to how the rising emphasis on spirituality is compatible with the inability to offer a common and effective response to the situations of crisis in society. I also ask what can be done about the underplayed dimensions of religion, ones that could aid us in taking the changes seriously without romanticizing the religion of the past and dreaming of its return.

Before going to the argument itself, let me briefly clarify the terms that I am using. I refer to religiosity when dealing with particular beliefs and practices that do not necessarily form one coherent whole, consisting of sacred narratives, rituals, religious experiences, doctrines, institutions, cultures and their monuments, etc., as, in various degrees, classical religions do. As will be pointed out, when speaking about current religiosity, we find fragments of different religions. Thus, religiosity and religion are not completely separated. Spirituality is seen as that dimension of both religion and religiosity, which deals with the inner life of people or of communities, seeking for and cultivating the relationship with what is seen as the ultimate.

\section{Responses to the Refugee Situation}

In the past few years, we have faced the heaviest movement of refugees and migrants since World War II. We all know the statistics. According to UNHCR, there are currently 65.6 million forcibly displaced people, 22.5 million of whom are refugees. Over half of them are under the age of 18 years. Eight million of them come from Syria and Afghanistan. The vast majority of refugees, according to the statistics $-86 \%$ - live in developing regions'; hence, Europe is faced only with a small percentage of those in urgent need. And yet it has shown itself unable to find a common approach to help that would come out of the values on which the European Union is based. Instead, although in a different intensity, various fears of others, of their national, cultural, and religious identity, are used in the public discourse as "reasons" to keep the refugees out. The governments of the Visegrad countries feature

1 See http://www.unhcr.org/figures-at-a-glance.html (accessed 2/6/2018); https://www.amnesty.org/ en/what-we-do/refugees-asylum-seekers-and-migrants/ (accessed 2/6/2018). 
among the least hospitable. ${ }^{2}$ While at first glance, the religious affiliation of the population of the four countries differs dramatically, ranging from those characterized as predominantly religious (Poland and Slovakia) to those understood as secular (the Czech Republic and Hungary), ${ }^{3}$ the political rhetoric "justifying" the fears frequently includes a claim to be upholding Christian values. ${ }^{4}$ The societies in these countries are divided. In the Czech Republic, there have also been the strongest civic protests against governmental policies since the fall of Communism, as well as subcultures promoting solidarity. Yet, the question remains as to why populist policies and politicians continue winning elections, and why their ideology including such a strong NO to helping people in need is successful. Are this current absence of solidarity and its religious justification linked to the separation of a predominantly individualized spirituality from other dimensions of religion? What role is played by the post-truth approach to religious values and claims?

\section{The Multidimensional Theory of Religion}

First, let us consider what, according to multidimensional theories of religion, complements the institutional, the doctrinal, the moral, and the spiritual aspects, which were mentioned so far. Multidimensional theories of religion go back to the mid-twentieth century. They offered a way of explaining how the essence of religion, something which cannot be fully conceptualized, is imprinted in human life. Thus, they spoke about the theoretical/doctrinal, the practical/cultic, and the sociological dimensions, the latter involving a system of social relations within religious groups, and also their relations to a broader society (Wach 1944). ${ }^{6}$ The dimensional theory helped sociologists, psychologists, and philosophers of religion, as well as theologians, to see more

2 In December 2017, the European Commission decided to take action against Poland, the Czech Republic, and Hungary, for refusing to participate in the refugee relocation scheme, and referred these three countries to the European Court of Justice. See https://www.amnesty.org/en/countries/europeand-central-asia/poland/report-poland/ (accessed 2/6/2018).

3 See, for example, "Religious Belief and National Belonging in Central and Eastern Europe," Pew Research Centre, 10 May 2017, http://www.pewforum.org/2017/05/10/religious-affiliation/ (accessed 4/6/2018).

4 For the abuse of Christian values rhetoric, see, for example, www.vlasteneckenoviny.cz/?p=196214 (accessed 2/6/2018).

5 Apart from the NGOs (such as People in Need, Amnesty International, Diakonie, Charita, Adra) who have been long-term helping both inside the country and abroad, new initiatives were established, such as Hate Free Zones, or simple events such as open breakfasts in mosques or churches. Perhaps the most significant new initiative has been the movement Students for Solidarity (https://studentizasolidaritu.ff.cuni.cz/en/who-are-we).

6 Wach's approach, although often considered as outdated - unjustly as Christian K. Wedemeyer points out - gave rise to further studies considering the typology and the multidimensionality of religion and religiosity (Wedemeyer 2010, xvii-xix). 
clearly the contours of the different aspects of the impact of religion on human life, their interaction in forming a religious identity, and what needs to be taken into account in their hermeneutics of religion or in their exploration of what constitute loci theologici - places out of which theology is done. The Scottish educationalist and Religious Studies' scholar Ninian Smart further specified that such investigations need to take on board doctrine but also the sacred narratives that ground and relativize it, ethics and rituals, institutions as well as religious experiences, and also on how the religious experience is expressed in the material objects people create, and in the political and economic relationships they cultivate (Smart 1969, 15-25, and Smart 1987, 296-8).

This nuanced approach did not claim that, in all classical religions in each period of history, one could find a balanced interaction of all the dimensions. Rather, it stressed that all the dimensions are important, all need to be considered, and if any was missing or downplayed, one should observe what happened to others. Smart's special interest as an educationalist lay in the link between spirituality and human values, and in how to strengthen this link when weak (Smart 1968, 105-6 and Rennie 1999). His insights are thus very useful both for understanding the state of traditional religions in countries like Poland and Slovakia, or in Western European countries where we still find a strong attachment to traditional religion, and for investigating the current religiosity which lies outside the classical religions, without being completely separated from them. Smart's sensitivity to the realm where people are neither sure about the existence of God nor of their atheism or agnosticism is valuable as we concentrate on the results of the European Values Study and their interpretations.

\section{What Comes after Secularization - The Czech Case Study}

Secularization was understood in European modernity as a process of emancipation from religion, in which religious thinking, practices, and institutions lost social significance. The turn of the twentieth and twentyfirst centuries brought new developments within this paradigm (see Martin 2005, Davie 1999). Thus, we now speak about different modes of the return of religion and spirituality into the public space and about its coexistence with what of the secularization paradigm is still alive.

7 Smart 1996 added two more dimensions, the material one, by which he meant objects or places symbolising or manifesting the sacred, and the political/economic dimension. In his different writings, both the names and the numbers of dimensions varied, but the basic intuition remained: the dimensional analysis helped to relate together religious experience and religious expression. 
I have chosen to look in more detail at the Czech Republic. It is different to a generally observable picture in other Central European countries such as Poland, Slovakia, or even Hungary as well as in parts of Eastern Europe. In these settings, religion returns to the public sphere along with nationalism. The dominant church offers itself as a "mother of the nation and a support of the throne," but while the majority within these societies see this as acceptable, it neither does inspire any religious revival nor does it draw on other dimensions of Christianity. Hence, relationship to the religious and ethnic minorities, to refugees and migrants, is not cultivated, for example, by Jesus's attitudes in the gospels or by the liturgical prayer for all or by the church's social teaching. The new identity discourse does not correspond to the content of Christianity, and it asks only for conformity to this ideological frame (Hamplová and Nešpor 2009). The Czech Republic fits neither of these models, though features of both are present. Indeed, we could even say there is a conflict between the two.

Unlike in other Visegrad countries, in the Czech Republic, the majority of the population is not interested in an ecclesial mediation of national identity. Churches are the least trusted institutions, especially when it comes to expressing political agenda.' In most cases, they do not offer a religiousideological underpinning of nationalist and xenophobic rhetoric. ${ }^{10}$ The churches generally do not play the role of mediator of religious meaning on behalf of those who do not take an active part in their life, except where there are personal relationships of trust established at a local level, or where people do not suspect the proximity of the church and political power. The interest in spirituality without religious belonging and without a profiled doctrinal content flourishes. But, it is increasingly difficult to find in such spirituality not only ties to institutions and doctrines but also any sound criteria for discernment between what is faith and what is superstition, what leads to human wholeness and what to transcendentalized self-centeredness.

8 I take this phrase from a lecture given by Pavel Hošek, "Náboženská situace české společnosti ve světle sociologických výzkumů jako východisko teologické reflexe," ["The Religious Situation of Czech Society in the light of Sociological Research as a Starting Point for Theological Reflection”]. The lecture was delivered at a meeting of the Protestant Theological Faculty of Charles University at Želiv, 8 June 2018. I also take the Eastern model characteristics from him.

9 David Václavík, Dana Hamplová, and Zdeněk Nešpor point out that while after the fall of Communism the trust in religious institutions reached up to $50 \%$, by the mid-1990s it had fallen by about a half, and now the level of trust oscillates between 25\% and 30\% (Václavík, Hamplová and Nešpor 2017).

10 One of the significant exceptions to this rule is the current Roman Catholic Archbishop of Prague, Cardinal Dominik Duka, who has a very close relationship to the president. But the strongest criticism of his position comes from within the Roman Catholic Church. 


\section{Contemporary Religiosity and the Absence of Solidarity With Those in Need}

Czech society is often mistakenly perceived as one of the most atheist and irreligious in Europe. According to the last census, only about 14\% of the population responded that they belonged to any religious organization. ${ }^{11} \mathrm{~A}$ further $7 \%$ considered themselves believers but without any institutional affiliation. 34\% claimed to be without confession and 45\% left the question unanswered. ${ }^{12}$ The low institutional self-identification is often mistaken for a high presence of atheism or for a lack of interest in religion. But the picture changes when we take on board other empirical research, in particular the results of large-scale international quantitative surveys such as the International Social Survey Programme (ISSP: 1991, 1998, 2008, 2018); European Values Study (EVS - 1981 (the Communist bloc did not participate); 1991, 1999, 2008, 2017), or the so far only independent Czech sociological survey exploring religion (Rabušic and Kafková 2010, 7; Rabušic and Hamanová 2009; Lužný, Nešpor et al. 2008; Hamplová 2008). ${ }^{13}$

The results which are available up till now show that it is much harder to find a convinced atheist (sometimes, in sociological terms called an analytical atheist - that is someone who consciously rejects any kind of transcendent, supernatural person or power, and has relatively clearly formulated reasons for such rejection) than people who have some form of religious faith. The percentage of convinced atheists is between $15 \%$ and $20 \%$, whereas those who identified themselves with some form of belief in God goes up to $50 \%$ (Vido, Václavík, and Paleček 2006; Nešpor 2012). When the content of that belief is further explored, we see that only about $10 \%$ identify themselves with a traditional Christian understanding of a personal God, whereas up to $40 \%$ preferred to speak about some supernatural power, life force, or spirit (Václavík, Hamplová and Nešpor 2017, 13 n12). If we take away 15-20\% of atheists, it leaves us still with $30-35 \%$ of people who either do not want to respond or do not know what to believe and what to think.

While we always need to take the results of empirical research with some reserve when it comes to details, the broad picture repeats itself. The majority

11 These were usually Christian churches, as the presence of other world religions in Czech Republic is very low: according to census adherence, Muslims and Jews would both be less than $0.04 \%$ of the population, though we need to take on board that not all of them would be registered. According to other studies, there are some 22,000 Muslims living in the Czech Republic (Šlechta et al., 2009). According to the Federation of Jewish communities, there are 15-20,000 Jews currently living in the Czech Republic (https://www.fzo.cz/o-nas/statistika). These figures both equate to some $0.2 \%$ of the population.

12 See https://www.czso.cz/csu/czso/nabozenska-vira-obyvatel-podle-vysledku-scitani-lidu-2011-61wegp46fl.

13 Regarding the scale: ISSP 2008 - 1512 respondents; EVS 2008 - 1821 respondents DIN 2006 1200 respondents. The data are available at ISSP Research Group (2012): International Social Survey Programme: Religion III - ISSP 2008. GESIS Data Archive, Cologne. ZA4950 Data file Version 2.2.0, doi:10.4232/1.11334 
of Czechs adhere to a kind of syncretistic and decentralized religiosity or spirituality, in which not only the institutional and doctrinal dimensions are, if not absent, significantly downplayed, but also sacred narratives, ritual, and ethics largely do not shape people's beliefs, values, and convictions. ${ }^{14}$ The new religiosity/spirituality is consumer-oriented and goes hand in hand with widespread illiteracy with regard to these dimensions of religion, leaving religious experience and material objects that people create in isolation, without giving them criteria for discernment that would emerge from interaction with other dimensions of religion. In addition, there is a strong NO to the political and economic relations that classical religion, in our case Christianity, forms or even could form. Such a situation makes the practitioners of decentralized and individualized spirituality vulnerable to the ideology of relativism utilized by populist politics.

But there are generational differences. The oldest generation (born before World War II) has the highest percentage of religious identification - but also it is among this generation that we very often find xenophobic attitudes. Hence, this generation would be the closest to the East European model. The middle generation is uprooted - in Grace Davie's phrase "believing without belonging" (Davie 2000 and 2002) - and contains the highest percentage of the vague religiosity/spirituality. Apart from the more esoteric forms of search, there is, however, also a serious interest in learning how to pray and how to meditate (this generation is predominantly present at spiritual retreats). It is mainly in this generation that now shapes our public life that religion returned to the public sphere, but it is the whole mixture of religion, ranging from the model of identity-building to the representative role of religion in the public sphere and a personal search for spirituality in the private sphere. The youngest generation - those who did not grow up under Communism often reject the vague religiosity of their parents. There is a higher percentage of people taking an active part in institutional religion but also a higher percentage of convinced atheists. When looking at the different initiatives of solidarity, young people, in particular students, represent the most active and able segment of the society, and they would be most often present at the demonstrations against populist policies (Laudátová and Vido 2010; CollinsMayo and Dandelion 2010; Polak and Rosta 2016; Arts and Halman 2013; Pollack, Müller, and Pickel 2012).

14 According to the research, less than $30 \%$ of respondents identify with any form of belief in heaven, hell, or resurrection, while more than $40 \%$ believe in the power of amulets, in the usefulness of horoscopes, and still more than 50\% in fortune telling (Václavík, Hamplová and Nešpor 2017, 14). 
The Czech case study offers an interesting picture. First, secularization that continues to influence public life coexists with the large-scale turn to a vague religiosity. This religiosity is not organized in any institutions, it does not have common core values and it lacks any structures that would enable a common action. Thus, it is reduced to the field of spirituality and culture while the realms of the practical, political, or economic life are, on the whole, left free of religious influence. Those who lived some of their adult life under the Communist regime are used to inconsistencies between the private and public spheres of life. In this sense, the continuous secularization of the public sphere and the post-secular turn of the private sphere easily coexist. Likewise, the division between who belongs to the life in the private sphere, and who does not, influences the attitude toward migrants and refugees in this generation. There are, however, generational differences.

Moreover, we need to take on board also the fact that the differentiation between what is considered to be public and what is considered to be private spheres of life have been disturbed. In the current liquid societies, not only are the traditional structures of life dissolved but also the very judgment that used to assist in discerning between the inner and the outer spheres (Bauman 2007; Han 2010; Han 2014). Hence, the non- or anti-institutional religiosity/ spirituality can, in some instances, absorb the populist link of religion, nationalism, and politics, and in other instances protests against it. It can adapt to the situation in the Western European countries where secularization is on the rise, as well as to Poland and Slovakia, where the pre-secular, the secular, and the post-secular convictions and practices form one whole. The Communist heritage, indeed, assists in the dissolution of structures of lives and of judgment (Havel 1985), but with regard to religiosity and its role in the societies, it is no longer the dominant influence.

\section{Re-Composition of Religion and Dissolving of the Criteria of Judgment}

The increasingly difficult agreement on common values in Europe is only partly due to the re-composition of religion and the "diffused spirituality," as Yves Lambert calls the amalgam of new religious movements, parascientific beliefs, and self-oriented spirituality (Lambert 2003). This plurality is an empirically demonstrated fact. However, the fact lives in interpretation, and in a public discourse the interpretation of the plurality is not free from fundamentalist overtones. Here, I mean a different sort of fundamentalism than religious fundamentalism; rather, its mirror image attacking any attempt at discernment between holy and unholy, good and bad, just and unjust, and marking them as remnants of a Christian imperialism or as 
fundamentalism. This happens even when such attempts go hand in hand with critique of the relation between religion and power and the critique of religious fundamentalism. Such attitudes draw on the post-modern critique of essentialism and direct such critique not only toward discernment but also toward the profiled notions of European heritage grounding such discernment (usually expressed as Hellenic and Christian, in some instances as Greek philosophy, Roman law, and Judeo-Christian religion, sometimes admitting that Islam also impacted on the European heritage). ${ }^{15}$ Patrick Fridlund, drawing on Derrida, says that the dominant Western discourse is criticized for its "hierarchical axiology." In it

values are ranked in dichotomized pairs like normal/abnormal, full/ empty, proper/parasitic, serious/non-serious, literal/non/literal, centre/ periphery, and essence/addition. There is a desire to find the original pure, proper, normal and essential, and only then - afterwards - to see deviations and the complications in what is held to be impure, parasitic and abnormal... (Fridlund 2011, 117).

The populist turn in European societies benefits from the dissolution of criteria of judgment. Coming back to the problem of Christian values being identified with xenophobia, nationalism, and exclusivism, when the difference between the proper and the parasitic is ruled out as an outdated essentialism, all interpretations are equally possible, and the public space is left for the least scrupulous and the loudest voice to win. The classical authors of the post-modern critique, such as Derrida or Lyotard, however, fought for something else than a post-truth and post-justice society. And their analysis also can be usefully turned against the extreme relativist positions, as such positions form nothing else than a mirror image of fundamentalism, or we could say a fundamentalism of a relativist provenance. It brings the end of communication, and of a common meaningful action. It does so by the upholding of an absolutist belief that none of the beliefs or convictions has more truth value than any other. The radical sameness - an opposite to the ranking and dichotomizing - assumes with an unquestionable certainty that all values and practices are equally good or bad, all practices are equally just or unjust, all statements have the same share in the truth and in the lie. Thus, a relativist fundamentalism is a perfect epistemological underpinning

15 The reductionist notion of European inherited identity is often associated with the notion of European soul. Ambrose In-Ren Mong OP comments on the identification of this soul as Christian, saying "Most people would acknowledge the Christian heritage of European culture, but the idea of promoting the 'myth of a Christian Europe' in order to exclude other religious and secular traditions is something else" (Mong 2014, 8). Werner Jeanrond argues against the notion, saying that it is more helpful to speak about a space than about a soul, and in particular, a space open for coexistence and cooperation of people of different religious traditions and secular beliefs (Jeanrond 2006, 185-6). 
for the post-truth and post-justice society, a perfect ground for that type of self-centered spirituality which petrifies one's self-interests as the ultimate. The post-modern critique can help in deconstructing such fundamentalism as well, to unmask it as an illusion, and to revive creativity, playfulness, and freedom necessary for re-establishing communication that would avoid both the dualist and the monist tyranny (Dolejšová (Noble) 2001, 33-43; Noble 2002; Noble 2005; Noble and Noble 2016).

\section{Pluralist Alternatives to Ideology of Relativism}

Regarding the analysis of the modern critique of religion and the dynamics between secularization and religion, we also find approaches, which work with religious plurality positively but in a non-relativist manner, such as those of Jürgen Habermas and Charles Taylor. In analyzing the unfinished project of modernity, Habermas places the religious and the non-religious elements within secularization as such. Their dialectics grounds the possibilities of a communicative action, such as a reflected and responsible help to refugees. Respect for difference and cooperation in commonly inhabited states, societies, and cultures must be, according to Habermas, open to a complementary learning process if we are to balance shared citizenship and cultural difference. The public sphere, then, is cultivated when human freedom and common action are joined together (Habermas 1981; Habermas 2001).

According to Charles Taylor, secular concepts meet their limit as they are ultimately incapable of providing a self-less center of the self, and of anchoring core values such as the value of the life of all, justice and good will, equal freedom and moral responsibility, the value of prevention of unnecessary death and suffering. Taylor rejects the "clash of civilizations" model of social interaction. Like Habermas, he seeks for a kind of communicative action that would join the multicultural, religiously, and morally plural world together. Recognizing the plurality not only outside but also within each religious tradition, with his special focus on Jewish, Christian, and Islamic thought, Taylor offers a nuanced answer to the question regarding the place religion takes both in forming an often aggressive reaction against secularization and a creative deconstruction of both secularist and religiously fanatical selfcenteredness (Taylor 1989; Taylor 2007).

We can also utilize other important sources in the secularization/postsecularization debate, such as the work of Jean Marie Domenach dealing with the possibilities of "ecological politics" while balancing religion with the need for autonomy and social conviviality (Domenach 1990; Domenach 1992; Domenach 1994; Domenach 1995). We can also draw on analyses of 
various other dimensions of the return of religion to the public sphere, or of the arguments that in one form or another religion has never left the public sphere (Berger 1999; Norris and Inglehart 2004; Juergensmeyer, Griego and Soboslai 2015). The multidimensional understanding of classical religions and of re-composed religiosity is vital, if we are not going to give up on criteria for judging between what is superstition and what is faith, what is selfish and what is generous, what is and what is not our responsibility in times of humanitarian crisis, etc. When appeals to classical religions, such as Christianity, or to Christian values become contentless, used to defend xenophobia and nationalism (Ramos, Pereira and Vala 2016; Roux 2014; Peral and Ramos 2013), it is easy to keep this absence of content in operation when negative sentiments against religious doctrines and institutions are exploited. Including other dimensions of religion, such as sacred narratives, ethics, and rituals may be helpful, not to convince others to return to the religious forms of the past, but rather to know that Jewish law demanded the protection of and hospitality toward orphans, widows, and strangers, that Jesus experienced the life of a refugee and his teaching called people toward responsibility for those who suffered. Or people need to know that in Christian liturgies we find prayers for those who are gathered in the churches but also for all people and for all the world. Historically, when religious experiences have been separated from such values, in the long term, they have not brought people well-being. Today, art and a good culture (those forms of culture which still cultivate) have wider possibilities to communicate such values than doctrine or religious institutions. But there are also examples of doctrines and institutions guarding freedom, love, and human creativity. The popularity of Pope Francis shows that such dimensions of religion can still bring something good beyond the churched population. Good theology still helps to interpret the symbolic wealth of tradition, it still offers keys for understanding freedom and conviviality in their horizontal and vertical expressions together. Working with many dimensions of religion is not a strategy for avoiding religious plurality, but rather for understanding religious plurality and appreciating what is good in it, provided we are still able to discern, even if the criteria we use are not infallible, and not even generally accepted across all the religioussecular spectrum.

Taking on board the results of the empirical research, we can claim that precisely spirituality and culture are able to assist most efficiently in dismantling the bond between the non-critical post-modern notion of interiority and the self-centered justifications of the absence of solidarity with others in need. Yet, as has been pointed out, it needs to be those forms of spirituality and 


\section{Contemporary Religiosity and the Absence of Solidarity With Those in Need}

culture in which criteria for discernment have been critically appropriated but not dissolved. Communication and search for a common ground is then crucial. With regard to religion and religiosity, such communication needs to involve people who identify themselves with some form of belief in God, some supernatural power, life force or spirit, as well as those who consider themselves agnostics or atheists. A common reflection on shared experiences can help not necessarily in building up new meta-criteria, but rather in giving weight and importance to the successful examples of discernment that emerge, uncovering the difference between when human life (personal and communal) flourishes, and when it does not; why it flourishes, and why it does not. Remembering the instances when such difference was recognizable makes people participate in a common tradition and makes it possible to celebrate the revelations of freedom, love, and conviviality with a genuine gratitude, and the gratitude. And gratitude may re-open the door to generosity.

\section{References}

Arts, Wil and Loek Halman, eds. 2013. Value Contrasts and Consensus in Present-Day Europe: Painting Europe's Moral Landscapes. Leiden: Brill.

Bauman, Zygmunt. 2007. Liquid Times: Living in an Age of Uncertainty. Cambridge: Polity Press.

Berger, Peter, ed. 1999. The Desecularization of the World: Resurgent Religion and World Politics. Grand Rapids, MI: Eerdmans.

Collins-Mayo, Sylvia and Pink Dandelion, eds. 2010. Religion and Youth, Farnham: Ashgate.

Davie, Grace. 1999. "Europe: The Exception That Proves the Rule?" In The Desecularization of the World: Resurgent Religion and World Politics, edited by Peter L. Berger, 65-83. Grand Rapids, MI: Eerdmans.

Davie, Grace. 2000. Religion in Modern Europe: A Memory Mutates. Oxford: Oxford University Press.

Davie, Grace. 2002. Predicting Religion: Christian, Secular, and Alternative Futures. Aldershot: Ashgate.

Domenach, Jean Marie. 1990. Europe: le défi culturel. [Europe: The Cultural Challenge.] Paris: La Découverte.

Domenach, Jean Marie. 1992. Une morale sans moralisme. [Morality without Moralism.] Paris: Flammarion.

Domenach, Jean Marie. 1994. La responsabilité: essai sur le fondement du civisme. [Responsibility: An Essay on the Foundations of the Civic Spirit.] Paris: Hatier.

Domenach, Jean Marie. 1995. Approches de la modernité. [Approaches to Modernity.] Paris: Ellipses.

Fridlund, Patrick. 2011. Mobile Performances: Linguistic Undecidability as Possibility and Problem in the Theology of Religions. Leuven: Peeters. 


\section{Journal of Nationalism, Memory \& Language Politics 13(2)}

Habermas, Jürgen. 1981. Theorie des kommunikativen Handelns I-II. [Theory of Communicative Action I-II.] Frankfurt am Main: Suhrkamp.

Habermas, Jürgen. 2001. Kommunikatives Handeln und detranszendentalisierte Vernunft. [Communicative Action and Decentralised Reason.] Stuttgart: Reclam.

Hamplová, Dana. 2008. “Čemu Češi věří: dimenze soudobé české religiosity”. ["What Do Czechs Believe In? Dimensions of Current Czech Religiosity”.] Sociologický časopis 44(4): 271-94.

Hamplová, Dana and Zdeněk Nešpor. 2009. "Invisible Religion in a 'Non-believing' Country: The Case of the Czech Republic.” Social Compass 56(4): 581-97.

ISSP Research Group (2012). International Social Survey Programme: Religion III - ISSP 2008. GESIS Data Archive, Cologne. ZA4950 Data file Version 2.2.0, doi:10.4232/1.11334.

Han, Byung-Chui. 2010. Müdigkeitgesellschaft. [Tired Society.] Berlin: Matthes \& Seitz.

Han, Byung-Chui. 2014. Burnoutgesellschaft. [Burnout Society.] Berlin: Matthes \& Seitz.

Havel, Václav. 1985. The Power of the Powerless. Armonk, NY: M.E. Sharpe.

Jeanrond, Werner. 2006. "The Future of Christianity in Europe." In Recognizing the Margins: Developments in Biblical and Theological Studies, edited by Werner Jeanrond and Andrew D.H. Mayers, 182-200. Dublin: The Columba Press.

Juergensmeyer, Mark, Dinah Griego, and John Soboslai. 2015. God in the Tumult of the Global Square: Religion in Global Civil Society. Oakland, CA: University of California Press.

Lambert, Yves. 2003. "New Christianity, Indifferences and Diffused Spirituality”. In The Decline of Christendom in Western Europe, 1750-2000, edited by Hugh McLeod and Werner Ustorf, 63-80. Cambridge: Cambridge University Press.

Laudátová, Marie and Roman Vido. 2010. "Současná religiozita v generační perspective." [“Contemporary Religiosity in a Generational Perspective.”] Sociální studia 4: 37-61.

Lužný, Dušan, Zdeněk R. Nešpor et al. 2008. Náboženství v menšině. Religiozita a spiritualita $v$ současné české společnosti. [Religion in a Minority. Religiosity and Spirituality in Contemporary Czech Society.] Praha: Malvern.

Martin, David. 2005. On Secularization: Towards a Revised General Theory. Aldershot: Ashgate.

Mong, Ambrose In-Ren. 2014. “The Crisis in Europe: An Examination of Joseph Ratzinger's Theological Vision.” Ecumenical Trends 43(1): 1-15.

Nešpor, Zdeněk R. 2012. "Náboženství a ateismus v současné české společnosti ve světle statistických a sociologických výzkumů." ["Religion and Atheism in Contemporary Czech Society in the light of Statistical and Sociological Research."] Salve. Revue pro teologii a duchovni život 22(1): 7-20.

Dolejšová (Noble), Ivana. 2001. Accounts of Hope: A Problem of Method in Postmodern Apologia. Bern: Peter Lang.

Noble, Ivana. 2002. “Apophatic Elements in Derrida's Deconstruction.” In Philosophical Hermeneutics and Biblical Exegesis, edited by Petr Pokorný and Jan Roskovec, 83-93. Tübingen: Mohr Siebeck. 


\section{Contemporary Religiosity and the Absence of Solidarity With Those in Need}

Noble, Ivana. 2005. "Postmoderní kritika." ["Postmodern Critique."] In Hermeneutika jako teorie porozumění [Hermeneutics as Theory of Understanding], edited by Petr Pokorný et al., 339-53. Praha, Vyšehrad.

Noble, Ivana and Tim Noble. 2016. "Hospitality as a Key to the Relationship with the Other in Levinas and Derrida." Acta Universitatis Carolinae Theologica 6(2): 47-65.

Norris, Pippa and Ronald Inglehart. 2004. Sacred and Secular: Religion and Politics Worldwide. Cambridge: Cambridge University Press.

Peral, Edurne Bartolomé and Alice Ramos. 2013. "Neighbours: Determinants of whom Europeans want to keep at a distance." In Value Contrasts and Consensus in Present - Day Europe: Painting Europe's Moral Landscapes, edited by Wil Arts and Loek Halman, 117-41. Leiden: Brill.

Pickel, Gert, Detlef Pollack, and Olaf Müller. 2012. "Differentiated secularization in Europe: Comparative Results". In The Social Significance of Religion in the Enlarged Europe: Secularization, Individualization and Pluralization, edited by Detlef Pollack, Olaf Müller and Gert Pickel), 229-55. Farnham: Ashgate.

Polak, Regina and Gergely Rosta. 2016. "Religion and Values in Central and Eastern Europe". In Focus on Religion in Central and Eastern Europe. A Regional View, edited by András Máté-Tóth and Gergely Rosta, 33-74. Berlin: De Gruyter.

Rabušic, Ladislav and Jana Hamanová. 2009. Hodnoty a postoje v $\check{C} R 1991$ - 2008. (Pramenná publikace European Value Study). [Values and Attitudes in the Czech Republic 1991-2008. A Source Publication of the European Values Study.] Brno: MUNI Press.

Rabušic, Ladislav and Marcela Petrová Kafková. 2010. "Editorial: European Values Study studnice informací o změně hodnot a postojů v ČR a v Evropě v posledních desetiletích”. ["Editorial: European Values Study - A Fount of Information on Changes in Values in the Czech Republic and Europe in the Past Decade"]. Sociálni studia 7(4): 7-9.

Ramos, Alice, Cícero Roberto Pereira and Jorge Vala. 2016. "Economic Crisis, Human Values and Attitudes towards Immigrants." In Values, Economic Crisis and Democracy, edited by Malina Voicu, Ingvill C. Mochmann and Hermann Dülmer, 104-37. Abingdon: Routledge.

Rennie, Brian S. 1999. "The View of the Invisible World: Ninian Smart's Analysis of the Dimensions of Religious Experience." The Bulletin of the Council of Societies for the Study of Religion 28(3): 63-8.

Roux, Guillaume. 2014. "Expliquer la xénophobie: valeurs culturelles, attitudes politiques et perception d'une menace." ["Explaining Xenophobia: Cultural Values, Political Attitudes and the Perception of a Threat."] In Les Valeurs des Européens: Evolutions et Clivages [European Values: Evolution and Cleavages], edited by Pierre Bréchon and Frédéric Gonthier, 73-88. Paris: Armand Colin.

Šlechta, Radomír Monika Vonšovská, Dominika Šimáčková and Lenka Trtíková. 2009. Život muslimů $v \check{C} R$. [The Life of Muslims in the Czech Republic.] http://www.hks.re/wiki/zivot_muslimu_v_cr. Accessed June 112018.

Smart, Ninian. 1969. The Religious Experience of Mankind. New York: Charles Scribner's Sons.

Smart, Ninian. 1987. "Religion." In A New Dictionary of Christian Theology, edited by Alan Richardson and John Bowden, 296-8. London: SCM. 


\section{Journal of Nationalism, Memory \& Language Politics 13(2)}

Smart, Ninian. 1996. Dimensions of the Sacred: An Anatomy of the World Beliefs. Berkeley, CA: California University Press.

Smart, Ninian. 1968. Secular Education and the Logic of Religion. New York: Humanities Press.

Taylor, Charles. 1989. Sources of the Self: The Making of the Modern Identity, Cambridge: Cambridge University Press.

Taylor, Charles. 2007. A Secular Age, Cambridge, MA: Harvard University Press.

Václavík, David, Dana Hamplová, and Zdeněk Nešpor. 2017. "Religious Situation in Contemporary Czech Society.” (2017) http://www.budoucnostnabozenstvi.cz/wp-content/uploads/2017/04/WHITE-PAPER_CZ_FINAL.pdf (accessed 11/6/2018)

Vido, Roman David Václavík, and Antonín Paleček. 2006. "Czech Republic: The Promised Land for Atheists?” In Sociology of Atheism, edited by Roberto Cipriani and Franco Garelli, 201-32. Leiden: Brill.

Wach, Joachim. 1944. Sociology of Religion. Chicago: University of Chicago Press.

Wedemeyer, Christian K. 2010. "Introduction I: Two Scholars, a 'School' and a Conference." In Hermeneutics, Politics, and History of Religions: The Contested Legacies of Joachim Wach and Mircea Eliade, edited by Christian K. Wedemeyer and Wendy Doniger, xv-xxvi. Oxford: Oxford University Press.

\section{Websites}

https://www.amnesty.org/en/countries/europe-and-central-asia/poland/report-poland/. Accessed June 22018.

https://www.amnesty.org/en/what-we-do/refugees-asylum-seekers-and-migrants/. Accessed June 22018.

https://www.czso.cz/csu/czso/nabozenska-vira-obyvatel-podle-vysledku-scitani-lidu2011-61wegp46fl. Accessed June 7 2018).

https://www.fzo.cz/o-nas/statistika. Accessed June 112018.

"Religious Belief and National Belonging in Central and Eastern Europe", Pew Research Centre, 10 May 2017. http://www.pewforum.org/2017/05/10/religious-affiliation/. Accessed June 42018.

http://www.unhcr.org/figures-at-a-glance.html. Accessed June 22018.

www.vlasteneckenoviny.cz/?p=196214. Accessed June 22018. 